\title{
Probability of HBsAg Among Village Midwives in Khartoum State, Sudan, 2014
}

\author{
Taha Ahmed Elmukashfi Elsheikh", , Yosra Mohammed Osman Abu Swait ${ }^{2}$, Siham Ahmed Balla ${ }^{1}$, \\ Abdelgadir Ali Bashir ${ }^{2}$, Asma Abdelaal Abdalla ${ }^{1}$
}

${ }^{1}$ Department of Community Medicine, Faculty of Medicine, University of Khartoum, Khartoum, Sudan

${ }^{2}$ Khartoum State Ministry of Health, Khartoum, Sudan

\section{Email address:}

tahamukashfi@hotmail.com (T. A. E. Elsheikh), tahamukashfi@uofk.edu (T. A. E. Elsheikh)

${ }^{*}$ Corresponding author

\section{To cite this article:}

Taha Ahmed Elmukashfi Elsheikh, Yosra Mohammed Osman Abu Swait, Siham Ahmed Balla, Abdelgadir Ali Bashir, Asma Abdelaal Abdalla. Probability of HBsAg Among Village Midwives in Khartoum State, Sudan, 2014. Science Journal of Public Health.

Vol. 5, No. 2, 2017, pp. 56-60. doi: 10.11648/j.sjph.20170502.11

Received: December 20, 2016; Accepted: December 29, 2016; Published: January 23, 2017

\begin{abstract}
The risk of catching HBV infection varies between and in-between health institutions as well as at geographical areas for general population. An observational study was performed in order to determine the conditional probabilities of the prevalence of HBsAg among Village Midwives in Khartoum State, Sudan, 2014. Through one stage stratified, systematic random sampling three hundred and thirty five village midwives out of 1848 were selected. A close end questionnaire for demographic data was used. Using Eliza, blood was tested; sera of all participants were examined for Anti-HBcore (IgG and IgM). Positive specimens for Anti-HBcore and HBsAg were examined for HBsAg and HBeAg respectively. Statistical package of social sciences (SPSS) version (16) and Chi-square test were used. $\mathrm{P} \leq 0.05$ was considered statistically significant. Probability was calculated manually using Bayesian analysis method. Participants were divided into three main age groups: (i) Age group less than 30 years (4.6\%). (ii) Age group (30-49) represented by 65.8\%. (iii) Age group more than 50 years $(29.5 \%)$. For education $(0.9 \%)$ university graduate, $(9.8 \%)$ secondary certificate, $(14.2 \%)$ intermediate, $(50.2 \%)$ primary, $(1.9 \%)$ Quranic School and (23\%) were illiterate. About (61.8\%) were married, (16.4\%) widow, $(11.3 \%)$ divorced and $(4.8 \%)$ un-married. Thirty four percent of them were positive for Anti-HBcore ( $\mathrm{IgG}$ ) indicating past or on going infection. Out of these fifty seven percent were HBsAg positive. HBeAg and Anti-HBcore ( $\operatorname{lgM})$ were negative. The maximum conditional probabilities of positive HBsAg in relation to age, educational level, marital status, and duration of work was found to be: (0.576), (0.524), (0.676), and (0.633) respectively. While the overall conditional probability in relation to these factors was: (0.576), (0.451), (0.14), and (0.633). Conditional probabilities of positive HBsAg among village midwives in Khartoum State, Sudan, were high. Village midwives with duration of work for 1-2 years and age above 50 years have got high probability of positive HBsAg. Screening and vaccination of village midwives are recommended.
\end{abstract}

Keywords: Conditional Probability, HBsAg, Village Midwives, Khartoum State, Sudan

\section{Introduction}

\subsection{Background Information}

Internationally, $\mathrm{HBV}$ is at the top of other diseases regarding morbidity and mortality [1]. HBV is highly infectious. It is $50-100$ times more infectious than HIV [2]. Healthcare providers are high risk groups for acquiring HBV infection in their institutions [3 - 5]. There is geographical and institutional variation for $\mathrm{HBV}$ infection. Anti-HBcore is $79.1 \%$ in Western Brazilian Amazon [6]. Anti-HBcore (22.2\%) and HBsAg (11\%) are reported in Southern Iran [7]. In Bangkok, $\mathrm{HBeAg}$, reflecting high infectivity rate, is $20 \%$ [8]. In sub-Saharan Africa, there are high numbers of HBV markers; above $60 \%$ for Anti-HBcore (indicating past or ongoing infection) and $8 \%$ for $\mathrm{HBsAg}$ (reflecting carrier rate) [9]. In Ethiopia, Nigeria and Tanzania, a carrier rate of 7\%$40 \%$ is reported. Burundi, Central African Republic and 
Uganda reported a range of a carrier rate $(\mathrm{HBsAg})$ between $10 \%-15 \%$ [10-14]. In Sudan, a carrier rate of $6 \%$ is reported among HCWs [15]. There is a significant correlation between occupational hazards and infection and carrier rates among HCWs in Public Hospitals in Khartoum State, Sudan [16]. Among general population in Gezira State, Central Sudan, the prevalence of infection (positive Anti-HBcore) and carrier (positive $\mathrm{HBsAg}$ ) is $47.5 \%$ and $6.9 \%$ respectively [1720]. HBV is highly endemic in Sudan, where it is ranked as the second cause of acute liver failure and the main cause of hepatocellular carcinoma [21]. Among health care providers in White Nile State, Sudan, there is a high prevalence and conditional probabilities of HBV markers. There is statistical association between carrier and highly infectivity rate of HBV and departments of Obstetrics \& gynaecology, surgery, Laboratory technicians and HCWs with working duration up to 5 years $[22,23]$

\subsection{Objective}

To determine the conditional probabilities of prevalence of HBsAg among Village Midwifes, in Khartoum State, Sudan, 2014.

\section{Materials and Methods}

\subsection{Study Design}

It is an observational survey.

\subsection{Study Area}

The study was conducted in Khartoum State, Sudan; which composed of seven localities (Bahri, Sharg-Anil, Khartoum, Jabal awlia, Omdurman, Ombeda, and Karari).

\subsection{Study Population}

They are 1848 village midwives that trained to provide care and advice during pregnancy, delivery and postpartum period and distributed in the seven localities of Khartoum State, Sudan, 2013.

\subsection{Sample Frame}

It includes all village midwives that responsible for provision of care and advice during pregnancy, delivery and postpartum period in Khartoum State, Sudan.

\subsection{Sampling Technique}

One stratified, systematic random sampling

\subsection{Sample Size}

It was calculated using the formula:

$$
\mathrm{n}=\frac{\mathrm{N}}{(\mathrm{N}-1) \mathrm{d}^{2}+1}=\frac{1848}{1847 \times 0.0025+1}=329
$$

$\mathrm{n}=$ sample size

$\mathrm{N}=$ Total number of VMWs in Khartoum State, Sudan $\mathrm{d}=5 \%=0.05$ desired margin of error

NRR $=$ Non-response rate $=1.8 \%$

So, $\mathrm{n}=329+6=335$

Depending on the number of village midwives, the sample was distributed among the different state localities as shown in Table 1 below:

Table 1. Distribution of the Sample Size of village midwives among Khartoum State Localities, Sudan, 2014. $(n=335)$.

\begin{tabular}{lll}
\hline Locality & No. of VMW & Sample Size \\
\hline BAHRI & $217(11.6 \%)$ & 39 \\
SHARG-ANIL & $480(26.0 \%)$ & 87 \\
KHARTUOM & $68(3.9 \%)$ & 13 \\
JABAL AWLIA & $293(15.8 \%)$ & 53 \\
OMDURMAN & $165(9.0 \%)$ & 30 \\
OMBEDA & $390(21.2 \%)$ & 71 \\
KARARY & $235(12.5 \%)$ & 42 \\
TOTAL & $1848(100 \%)$ & 335 \\
\hline
\end{tabular}

\subsection{Data Collection}

- Study variables are:

A. Independent variables: 1. Age. 2. Level of education. 3. Marital status. 4. Duration of work.

B. Dependant variables: 1. Anti-HBcore (IgG). 2. AntiHBcore (IgM). 3. HBsAg. 4. HBeAg.

- Tools of data collection: Questionnaire for demographic factors and blood sample for determination of HBV markers.

\subsection{Data Analysis}

Eliza was used. Sera of all participants were examined for Anti-HBcore (IgG and IgM). Positive specimens for AntiHBcore and HBsAg were examined for HBsAg and $\mathrm{HBeAg}$ respectively. Statistical package of social sciences (SPSS) version (16) and Chi-square test were used. $P$ value equal or less than 0.05 was considered statistically significant. Probability was calculated manually using Bayesian analysis formula below:

$$
\operatorname{Pr}\left(A_{i} / B_{j}\right)=\operatorname{Pr} \frac{\left(A_{i} \cap B_{j}\right)}{\operatorname{Pr}\left(B_{j}\right)}=\operatorname{Pr}\left(A_{i}\right) * \frac{\operatorname{Pr}\left(B_{j} / A_{i}\right)}{\operatorname{Pr}\left(B_{j}\right)}
$$

\section{Application of Bayesian Analysis:-}

Bayesian analysis was used for prediction, where the prior probability of the rate of $\mathrm{HBV}$ infection, carrier was calculated manually, given additional information about the village midwives in Khartoum State, Sudan. For medical and policy purposes, Bayesian analysis is usually used to infer and predict these rates, so that policy makers can react accordingly.

\section{Ethical Consideration}

Ethical approval was processed by Sudan Medical Specialization Board and Khartoum State Ministry of Health. Finally written consent from participants was taken. 


\section{Results}

Three hundred and thirty five female village midwives participated in this study. Regarding locality distribution of the sample, (11.6\%) in Bahri, (26.0\%) in Sharg-Anil, (3.9\%) in Khartoum, (15.8\%) in Jabal awlia, (9.0\%) in Omdurman, $(21.2 \%)$ in Ombeda, and (12.5\%) in Karari. The participants divided into three main age groups: (i) Age group less than 30 years $(4.6 \%)$. (ii) Age group (30-49) represented by
65.8\%. (iii) Age group more than 50 years (29.5\%). For education: university graduate $(0.9 \%)$, secondary certificate $(9.8 \%)$, intermediate $(14.2 \%)$, primary $(50.2 \%)$, Quranic School $(1.9 \%)$ and illiterate $(23 \%)$. About $(61.8 \%)$ were married, (16.4\%) widow, (11.3\%) divorced and (4.8\%) unmarried. Thirty four percent (113) of them were positive Anti-HBcore (IgG) indicating past or on going infection. Out of these fifty seven percent (57) were HBsAg positive. $\mathrm{HBeAg}$ and Anti-HBcore ( $\operatorname{lgM})$ were negative.

Table 2. Probability of HBsAg among village midwife characteristics, given that a village midwife is positive for Anti-HB core (IgG), in Khartoum State, Sudan; 2014 .

\begin{tabular}{|c|c|c|c|c|c|}
\hline \multicolumn{2}{|c|}{$\begin{array}{l}\text { Village midwife } \\
\text { characteristics }\end{array}$} & \multirow{2}{*}{$\begin{array}{l}\text { +ve Anti-HB core (IgG) }(\mathbf{n}=\mathbf{1 1 3}) \\
\operatorname{Pr}\left(B_{j}\right) \\
0.533\end{array}$} & \multirow{2}{*}{$\begin{array}{l}\text { Joint Probability. } A_{i} \cap B_{j} \\
0.211\end{array}$} & \multirow{2}{*}{$\begin{array}{l}\text { Conditional Probability. } \\
\operatorname{Pr}\left(A_{i} / B_{j}\right) \\
0.396\end{array}$} & \multirow{2}{*}{$\begin{array}{l}\text { P- } \\
\text { Value } \\
0.026\end{array}$} \\
\hline & $<30$ years & & & & \\
\hline & $30-49$ & 0.341 & 0.139 & 0.408 & 0.001 \\
\hline Age & $>50$ years & 0.302 & 0.174 & 0.576 & 0.001 \\
\hline & Missing & 0.300 & 0.112 & 0.373 & 0.3 \\
\hline \multirow{10}{*}{ Education } & TOTAL & 0.337 & 0.034 & 0.101 & 0.001 \\
\hline & Postgraduate & 1.00 & 0.337 & 0.337 & \\
\hline & University & 0.00 & 0.000 & 0.000 & \\
\hline & Secondary & 0.355 & 0.153 & 0.431 & 0.003 \\
\hline & Intermediate & 0.378 & 0.198 & 0.524 & 0.001 \\
\hline & Primary & 0.302 & 0.126 & 0.417 & 0.001 \\
\hline & Quranic School & 0.000 & 0.000 & 0.000 & \\
\hline & Illiterate & 0.37 & 0.175 & 0.473 & 0.001 \\
\hline & Missing & 0.50 & 0.150 & 0.300 & 0.082 \\
\hline & TOTAL & 0.337 & 0.152 & 0.451 & 0.001 \\
\hline \multirow{6}{*}{$\begin{array}{l}\text { Marital } \\
\text { status }\end{array}$} & Married & 0.343 & 0.143 & 0.417 & 0.001 \\
\hline & Single & 0.250 & 0.169 & 0.676 & 0.05 \\
\hline & Widow & 0.345 & 0.177 & 0.513 & .001 \\
\hline & Divorce & 0.316 & 0.169 & 0.535 & 0.001 \\
\hline & Missing & 0.368 & 0.145 & 0.394 & 0.036 \\
\hline & TOTAL & 0.337 & 0.140 & 0.415 & 0.001 \\
\hline \multirow{7}{*}{$\begin{array}{l}\text { Duration } \\
\text { of work }\end{array}$} & $<1$ year & 0.333 & 0.000 & 0.000 & \\
\hline & $1-2$ years & 0.267 & 0.169 & 0.633 & 0.057 \\
\hline & 2- 5 years & 0.462 & 0.169 & 0.366 & 0.07 \\
\hline & $5-10$ years & 0.455 & 0.090 & 0.198 & 0.033 \\
\hline & $10-20$ years & 0.287 & 0.174 & 0.606 & 0.001 \\
\hline & $>20$ years & 0.290 & 0.135 & 0.466 & 0.001 \\
\hline & TOTAL & 0.337 & 0.152 & 0.451 & 0.001 \\
\hline
\end{tabular}

\subsection{Age Factor}

The highest conditional probability $(0.576$; $\mathrm{P}$-value $=$ 0.001 ) for a village midwife to be HBsAg positive (carrier), given that she is Anti-HBcore positive (infected) was reported among the age group above 50 years. The overall conditional probability for a village midwife to be $\mathrm{HBsAg}$ positive (carrier), given that she is Anti-HBcore positive (infected) was 0.576; $(\mathrm{P}$-value $=0.001)$. [Table 2].

\subsection{Education Level Factor}

Considering the different levels of education, the maximum conditional probability $(0.524$; P-value $=0.001)$ for a village midwife in Khartoum State, Sudan, to be a carrier (positive HBsAg) given that she an infected (positive Anti-HBcore), was found among the intermediate school graduates, while the minimum conditional probability (0.000) was reported among university and Quranic school graduates. The overall conditional probability of a village midwife to be a carrier (+ve HBsAg) given that she is infected (+ve AntiHBcore), in relation to education, equals 0.451; (P-value $=$
0.001). [Table 2].

\subsection{Marital Status Factor}

For marital status, the maximum conditional probability (0.676) for a village midwife in Khartoum State, Sudan, to be a carrier (positive HBsAg) given that she is infected (positive Anti-HBcore) was reported among unmarried (single) group. $\mathrm{P}$-value $=0.05$. The overall conditional probability for a village midwife, with regard to marital status, to be HBsAg positive (carrier), given that she is Anti-HBcore positive (infected) was 0.14; $(\mathrm{P}$-value $=0.001)$. [Table 2].

\subsection{Duration of Work Factor}

Regarding duration of work and the probability for the village midwife to be a carrier (positive HBsAg) given that she is infected (positive Anti-HBcore), the maximum score (0.633; P-value $=.05)$ was reported among those who worked for 1-2 years, followed by $10-20$ years a probability of (0.606; P-value $=0.001)$. The overall conditional probability for a village midwife, with regard to duration of work, to be HBsAg positive (carrier), given that she is Anti-HBcore 
positive (infected) was $0.451 ;(\mathrm{P}-$ value $=0.001)$. [Table 2].

\section{Discussion}

Three hundred thirty five village midwives in Khartoum State, Sudan, were investigated for HBV markers. One hundred and thirteen (34\%) were found to be positive for Anti-HBcore (IgG), reflecting the infection rate among them. Probability of HBV carrier rate (positive HBsAg) among village midwives, given that she is infected (positive AntiHBcore) was studied using Bayesian analysis method. The rate of HBV infection (positive Anti-HBcore) reported in this study $(34 \%)$ is less than that among general population in Western Brazilian Amazon (79.1\%) and sub-Saharan Africa $(60 \%)[6,9]$. This may be due to that our study population is selective, i.e. special group. But it is higher than that in Southern Iran (22.2\%) [7]. Looking at national studies in Sudan, infection rate is high among HCWs in White Nile State in Sudan, where it is mounted to $60 \%$ [24]. The possible explanation is that the rate of exposure of HCWs in these hospitals to HBV infection is higher than that of our study population. The maximum conditional probabilities in relation to age, educational level, marital status, and duration of work was found to be: $(0.576),(0.524),(0.676)$, and (0.633) respectively. While the overall conditional probability in relation to these factors was: $(0.576),(0.451),(0.14)$, and (0.633). Regarding age factor, the highest conditional probability for carrier rate $(0.576)$ was reported among the age group above 50 years. HBV is highly endemic in Sudan. So, when the candidate contracted this infection early in life the chronic level may be more than $90 \%$, i.e. high level of carrier rate. [21]. For education, the maximum conditional probability was related to intermediate graduate; while the minimal value was among university together with Quranic School graduates. This may be because the graduates of university were more aware than others, while the behaviour of Quranic School graduates is guarded by the Islamic religious regulations. About the marital status, the maximum conditional probability for a village midwife in Khartoum State, Sudan, to be a carrier (positive HBsAg) given that she is infected (positive Anti-HBcore) was reported among unmarried (single) group. This is consistent with studies done in Nigeria that showed high rates of HBsAg among illiterate, unmarried pregnant women attending ante natal care, and among HCWs in White Nile State, Sudan. [22, 25]. Regarding duration of work and the probability for the village midwife to be a carrier (positive HBsAg) given that she is infected (positive Anti-HBcore), the maximum score was reported among those who worked for 1-2 years, followed by 10-20 years. This finding is similar to a study done among HCWs in White Nile State, Sudan. [22].

\section{Conclusion and Recommendations}

Conditional probabilities of $\mathrm{HBV}$ carrier rate among village midwives in Khartoum State were high. Village midwives with duration of work for 1-2 years and age above
50 years have got high carrier rate. Screening and vaccination of village midwives are highly recommended.

\section{References}

[1] Mahgoub, S., Candotti, D., El-Ekiaby, M., \& Allain, J. P. (2011). Hepatitis B virus (HBV) infection and recombination between HBV genotypes $\mathrm{D}$ and $\mathrm{E}$ in asymptomatic blood donors from Khartoum Sudan. J Clin Microbiol, 49, 298-306. http://dx.doi.org/10.1128/JCM.00867-10.

[2] World Health Organization [WHO]. (2012). Hepatitis B Fact sheet $\mathrm{N}^{\circ} 204$, July 2012.

[3] Deuffic-Burban, S., Delarocque-Astagneau, E., Abiteboul, D., Bouvet, E., \& Yazdanpanah, Y. (2011). Blood-borne viruses in health care workers: prevention and management. J Clin Virol, 52. http://dx.doi.org/10.1016/j.jcv.2011.05.016.

[4] Mele, A., Spada, E., Sagliocca, L., Ragni, P., Tosti, M. E., Gallo, G., et al. (2001). Risk of parenterally transmitted hepatitis following exposure to surgery or other invasive procedures: results from the hepatitis surveillance system in Italy. J Hepatol, 35, 284-9. http://dx.doi.org/10.1016/S01688278 (01)00111-8.

[5] De Schryver, A., Claesen, B., Meheus, A., van Sprundel, M., \&François, G. (2011). European survey of hepatitis B vaccination policies for healthcare workers. Eur $J$ Public Health, 21, 338-43. http://dx.doi.org/10.1093/eurpub/ckq122.

[6] Castilho, M. C., Oliveira, C. M., Gimaque, J. B., Leão, J. D., \& Braga, W. S. (2012). Epidemiology and molecular characterization of hepatitis $B$ virus infection in isolated villages in the Western Brazilian Amazon. Am J TropMed Hyg, 87, 768-74. http://dx.doi.org/10.4269/ajtmh.2012.120083.

[7] Mohammad, R. F., Davood, M., Sara, M., Najmeh, Z. J., Abbas, A., \& Mohammad, A. D. (2014). The Seroprevalence of Hepatitis B in Akbar Abad Village, Kavar, Southern Iran. International Journal of Preventive Medicine, hepatitis, 5 (S3), S223-S230.

[8] Luksamijarulkul, P., Maneesri, P., \& Kittigul, L. (1995). Hepatitis B sero prevalence and risk factors among school age children in a low socioeconomic community, Bangkok. Asia Pac J Public Health, 8, 158-61. http://dx.doi.org/10.1177/101053959500800302.

[9] Parkin, D. M., Bray, F., Ferlay, J., \& Pisani, P. (2005). Global cancer statistics, 2002. Cancer J Clin, 55 (2), 74-108. http://dx.doi.org/10.3322/canjclin.55.2.74.

[10] de Lalla, F., Rizzardini, G., Rinaldi, E., Santoro, D., Zeli, P. L., \& Verga, G. (1990). HIV, HBV, delta-agent and Treponema pallidum infections in two rural African areas. Trans $R$ Soc Trop Med Hyg, 84, 144-7. http://dx.doi.org/10.1016/00359203 (90)90412-8.

[11] Pawlotsky, J. M., Bélec, L., Grésenguet, G., et al. (1995). High prevalence of hepatitis B, C, and E markers in young sexually active adults from the Central African Republic. $J$ Med Virol, 46, 269-72. http://dx.doi.org/10.1002/jmv.1890460318.

[12] Pellizzer, G., Blè, C., Zamperetti, N., et al. (1994). Serological survey of hepatitis B infection in Tanzania. PublicHealth, 108, 427-31. http://dx.doi.org/10.1016/S0033-3506 (94)80100-2. 
[13] Ejele, O. A., \& Ojule, A. C. (2004). The prevalence of hepatitis B surface antigen (HBsAg) among prospective blood donors and patients in Port Harcourt, Nigeria. Niger $J$ Med, $13,336-8$.

[14] Abebe, A., Nokes, D. J., Dejene, A., Enquselassie, F., Messele, T., \& Cutts, F. T. (2003). Seroepidemiology of hepatitis B virus in Addis Ababa, Ethiopia: Transmission patterns and vaccine control. Epidemiol Infect, 131, 757-70. http://dx.doi.org/10.1017/S0950268803008574.

[15] Elmukashfi, T. A., Ibrahim, O. A., Elkhidir, I. M., Bashir, A. A., \& Elkarim, M. A. A. (2012). Socio-demographic characteristics of health care workers and hepatitis B virus (HBV) infection in public teaching hospitals in Khartoum State, Sudan. Global journal of health science, 4 (4), 37. http://dx.doi.org/10.5539/gjhs.v4n4p37.

[16] [16]. Elmukashfi, T. A., Ibrahim, O. A., Elkhidir, I. M., Bashir, A. A., \& Elkarim, M. A. A. Occupational Hazards and HBV infection among health care workers in Public Teaching Hospitals in Khartoum State, Sudan: A multiple Discriminant Analysis. Sudan JMS Vol. 7, No. 1. Mar 2012.

[17] WHO. (1996). Expanded program on immunization, hepatitis $B$ vaccine, making global progress: EPI update. Geneva, Switzerland: World Health Organization; October, 1996.

[18] Mudawi, H. M., Smith, H. M., Rahoud, S. A., Fletcher, I. A., Saeed, O. K., \& Fedail, S. S. (2007). Prevalence of hepatitis B virus infection in the Gezira state of central Sudan. Saudi $J$ Gastroenterol, 13, 81-3. http://dx.doi.org/10.4103/13193767.32182 .

[19] McCarthy, M. C., el-Tigani, A., Khalid, I. O., \& Hyams, K. C. (1994). Hepatitis B and C in Juba, southern Sudan: results of a serosurvey. Trans $R$ Soc Trop Med Hyg, 88, 534-536. http://dx.doi.org/10.1016/0035-9203 (94)90150-3.
[20] Hatim, M. Y. M. (2008). Epidemiology of viral hepatitis in Sudan. Clinical and Experimental Gastroenterology, 1, 9-13.

[21] Elduma, A. H., \& Saeed, N. S. (2006). Hepatitis B virus infection among staff in three hospitals in Khartoum, Sudan, 2006-07. EMHJ, 17 (6), 274-278.

[22] Elmukashfi T. A., Balla S. A., Bashir A. A., Abdalla A. A., Abu Elgasim M. A., \& Swareldahab Z. Conditional Probabilities of HBV markers among Health Care Workers in Public Hospitals in White Nile State, Sudan; 2013. Global Journal of Health Science; Vol. 9, No. 5; 2017. Pages (10-17). doi: 10.5539/gjhs.v9n5p10 URL: http://dx.doi.org/10.5539/gjhs.v9n5p10.

[23] Elmukashfi T. A., Bashir A. A., Balla S. A., Abdalla A. A., Abu Elgasim M. A., \& Swareldahab Z. Analysis of Hazards for Hepatitis B Virus, Across Departments and Occupations, Among Health Care Workers in Public Hospitals in White Nile State, Sudan, 2013. American Journal of Health Research 2016; 4 (5): 117-120. http://www.sciencepublishinggroup.com/j/ajhr. doi: 10.11648/j.ajhr.20160405.11. ISSN: 2330-8788 (Print); ISSN: 2330-8796.

[24] Elgasim et al.; Prevalence of Anti-HBcore Total and HBsAg among Health Care Workers in Public Hospitals, White Nile State, Sudan; 2013. BJMMR, 14 (9): 1-17, 2016.

[25] Pennap, G. R., Osanga, E. T., \& Ubam, A. (2011). Seroprevalence of Hepatitis B Surface Antigen among Pregnant Women Attending Antenatal Clinic in Federal Medical Center Keffi, Nigeria. Res J Med Sci, 5 (2), 80-82. http://dx.doi.org/10.3923/rjmsci.2011.80.82. 